\title{
Tourism Destination Image of Bali According to European Tourist
}

\author{
Utama, I.G.B.R. \\ Dhyana Pura University, Hospitality Management Department \\ Bali, Indonesia \\ raiutama@undhirabali.ac.id
}

\begin{abstract}
This research was conducted in the province of Bali which aims to determine the attraction factors as the main attraction of tourism Bali from perspective of European, and also to determine the factors that predominantly determine European travel to Bali. The research was designed by using research survey that involving 167 European tourists. Exploratory factor analysis techniques are used to analyze a wide range of variables Balinese charm. The main attraction of tourism Bali are (1) the immigrations, security of destinations, and travel agencies, (2) the prices, the accommodations, foods and transportations, (3) the history, culture, and natural beauty. While the most dominant factors in determining European tourists traveled to Bali are immigrations, security destinations, and travel agencies. The study's findings also indicate that the images of Bali tourism are the destination's history, culture, and nature.
\end{abstract}

Keywords - destination image, charm, history, culture, scenery, European tourists

\section{INTRODUCTION}

Recently, many people assume that the culture of Bali is the main attraction of tourism Bali has undergone a change and even considered has been degraded. In the similar side, natural resources of Bali also considered to have been degraded over the development of tourism in Bali. However, the fact of those tourist arrivals of European tourists are quite sensitive to both issues that actually increased to 135,215 people during for two month period from January to February 2016. The increasing numbers are accounted for 18.61 percent or 726,625 people of all foreign tourists who traveled to Bali. The arrivals of European tourists who travel to Bali every month are increased by 67,026 people during January, to 68,219 people in February 2016. Although the economic conditions of Europe have not been too favorable, but tourists from that region remained increasing consistently. The increasing number of European tourist is considered that Bali Island has power to attract them to visit Bali.

Indeed, tourism market share can be divided by various categories, such categories of origin, age, occupation, education, etcetera which can be observed empirically. This study was conducted to explore the existences of important tourist attraction variables to determine which factors are as the main attraction of Bali from the perspective of European tourist who visited Bali. This study is exploratory analysis to determine the existence of the tourist attraction of Bali Island as the tourism destination from perspective of European tourist. The research problems are defined in this study: (1) what factors are the main attraction of Bali destination from perspective European tourist? (2) Which factors determine the dominant European tourist to visit Bali?

\section{LITERATURE REVIEW, THEORY AND CONCEPTS}

Currently, there are still a lot of debating on differing views on the components about the image of the destination. For example, Fakeye and Crompton assumed that the destination image consists of only cognitive component, whereas perceptual or cognitive evaluation only refers to an individual's knowledge and belief in an object perceived or evaluated [1]. Mazursky and Jacoby considered that consumers build an overall image based on the evaluation of various attributes that consist of goods and services [2]. Likewise, Gartner stated that the perception of tourists to various destinations attributes will interact in shaping the image of the overall image [3]. However, Keown et al., have been tested by the empirical fact that there is a relationship between cognitive attributes and overall image, and conclude that the overall impression is dependent upon the attributes of destinations based on the perception of tourists individually [4].

Milman and Pizam stated that cognitive offers three components that determine the image of destinations, namely: attractions, the host's behavior and attitude, and the environments such as climate, facilities, and etcetera [5]. Meanwhile, Goeldner and Ritchie identified that cognitively, destination image consists of a psychological component rating, uniqueness, and destination attributes holistically [6]. Furthermore, Chi has conducted research and classify the nine attributes that affect the overall image of the destination, namely (1) the attributes of nature, (2) the opportunities rating for fun and recreations, (3) the natural environments, (4) public facilities, (5) the cultures, histories, and arts, (6) the social environments, (7) the tourism infrastructures, (8) economic and political factors, and (9) the atmosphere destinations [7]. In order to maintain and improve the growth of the market segment of European tourists, required creativity and innovation in managing the business and product packaging to reach the preferences of tourists, especially European tourists. The behavior of European tourists can be seen from their lifestyle based on the dimensions of cultural 
differences, which can be seen from the dimensions of self attitude and lifestyle dimensions simultaneously.

This study is the exploration of the existences of the Bali tourism attractions with the participation of European tourists. This research is expected to result in significant and meaningful information for sustainability of Bali tourism destinations. In this context it becomes important to investigate the attractions and motivations of European tourist to visit Bali. The image and destination attractions are perception formed from a variety of information received by tourists. Each tourism destination has particular attraction and image that contains beliefs, impressions, and perceptions of a destination. The image formed is a combination of various factors that exist in destinations such as the weather, landscapes, security, health and sanitations, hospitality, and others [8][9]. Attractiveness and image of the destination is always experiencing the dynamics over the development technology, communication and information should be more used by media, audio, visual and so research on the image of destinations should be done so that these dynamics can be determined.

\section{RESEARCH METHOD}

The quantitative approaches are used in this study to find the attraction destination variables from perspective of European tourists. The application of theories and concepts related destinations to formulate the strategy so that the number of European tourists who visit Bali can be increased.

This research was conducted in the province of Bali in periode of April to August 2016, and was designed using research survey to collect data that involving 167 European tourists as respondents. The respondents were selected purposively when they are on vacation in Bali. Exploratory factor analysis techniques are used to analyze a wide range of destination attraction factors that expected to produce a couple of dominant factors determining the European tourists.

Factor analysis is done through the various phases that define a number of variables corresponding to research problems, then determine the adequacy of the respondents, and then factor analysis with rotation of factors, grouping factor, then the naming factor appropriate representation of the variable constituent, and the last stage is determine factor model accuracy [10].

\section{RESEARCH FINDING AND EXPLANATION}

\section{A. Respondent Profile}

Based on their gender groups of 167 respondents who participated in this study, illustrated that male respondents are more dominant which is about 58.1 percent compared with the female respondents which is about 41.9 percent, that can be seen as on the Table 1 below:
TABLE I. RESPONDENTS PROFILE BY GENDER

\begin{tabular}{|l|c|c|}
\hline \multicolumn{1}{|c|}{ Gender } & Number of Respondent & Percentage \\
\hline Male & 97 & 58.1 \\
\hline Female & 70 & 41.9 \\
\hline Total & 167 & 100 \\
\hline \multicolumn{2}{|c|}{ Source: Primary Research Finding, 2016 }
\end{tabular}

However, based on the frequency of their visiting Bali from 167 respondents are illustrated that the dominant respondents had traveled more than twice to Bali which is about 46.7 percent, 33.5 percent for visiting in the first time, and 19.8 percent visited Bali for the second time as seen as in Table 2 below:

TABLE II. THE FREQUENCY OF THEIR VISITING BALI

\begin{tabular}{|l|c|c|}
\hline \multicolumn{1}{|c|}{ Visiting Bali } & Number of Respondent & Percentage \\
\hline Second visit & 33 & 19.8 \\
\hline More than twice & 78 & 46.7 \\
\hline First time visit & 56 & 33.5 \\
\hline Total & $167 \quad$ Source: Primary Research Finding, 2016 \\
\hline
\end{tabular}

Based on their nationality of 167 respondents, reflected that respondents mainly from the Dutch about 24.6 percent, and German about 16.2 percent, French about 9.6 percent, British 9 percent and the Italian, Swiss, Russian, Swede, Belgian, Spaniard, Finn, Irish, Dane, the Norway, Others as seen as on Table 3 below:

TABLE III. NATIONALITY OF RESPONDENTS

\begin{tabular}{|l|c|c|}
\hline Nationality & Number of Respondent & Percentage \\
\hline Dutch & 41 & 24.6 \\
\hline German & 27 & 16.2 \\
\hline French & 16 & 9.6 \\
\hline British & 15 & 9.0 \\
\hline Italian & 13 & 7.8 \\
\hline Swiss & 13 & 7.8 \\
\hline Russian & 8 & 4.8 \\
\hline Swede & 8 & 4.8 \\
\hline Belgian & 7 & 4.2 \\
\hline Spaniard & 4 & 2.4 \\
\hline Finn & 3 & 1.8 \\
\hline Irish & 3 & 1.8 \\
\hline Dane & 2 & 1.2 \\
\hline Norwegian & 2 & 1.2 \\
\hline Others & 5 & 3.0 \\
\hline Total & 167 & 100 \\
\hline
\end{tabular}

\section{B. Images of Bali According European Tourists}

The finding of the survey from 167 respondents as seen as on Table 4 were analyzed using statistic description based on the main destination attractions of Bali, that can indicate the variables of the beauty of the scenery, Balinese culture, and history of Bali are ranked on the top ranking that means they have a very strong attractiveness to attract European tourists to visit Bali. 
TABLE IV. THE PERCEPTION OF EUROPEAN TOURISTS ABOUT BALI

\begin{tabular}{|l|c|c|c|}
\hline Variables & Mean & Remarks & Rank \\
\hline The beauty of the scenery & 4.4431 & Very good & 1 \\
\hline Balinese Culture & 4.3413 & Very good & 2 \\
\hline History of Bali & 4.2754 & Very good & 3 \\
\hline Variations Travel Attractions & 3.9401 & Good & 4 \\
\hline Events and Festivals & 3.9222 & Good & 5 \\
\hline The Variant of Culinary & 3.8503 & Good & 6 \\
\hline Prices of Goods and Services & 3.6946 & Good & 7 \\
\hline Distance from Origin Country & 3.6407 & Good & 8 \\
\hline Facilities and Services Hotel & 3.5389 & Good & 9 \\
\hline Transportation & 3.3952 & Average & 10 \\
\hline Quality of Service Travel Agent & 3.3772 & Average & 11 \\
\hline Facilities and Services Wellness & 3.3353 & Average & 12 \\
\hline Security on Destinations & 3.2874 & Average & 13 \\
\hline Quality Services Guides & 3.2395 & Average & 14 \\
\hline Immigration services & 3.0599 & Average & 15 \\
\hline
\end{tabular}

Remark: $(1,00-1,80=$ Very bad), $(1,81-2,60=$ bad $),(2,61-3,40$

= Average $),(3,41-4,20=$ Good $),(4,21-5,00=$ Very good $)$

While the variables that have the average perceptions are the security of destinations, service guides, and immigration services. All these three variables indicate that these are still not fully convinced them that traveled to Bali from perspective of European tourists. However, from the 15 variables were analyzed descriptively, show that the variation of attractions, events and festivals, culinary, prices of goods and services, the distances from the country of origin, the facilities and the hotel services, transportations, quality of services of travel agent, as well as facilities and wellness services are evaluated enough to convince respondents that traveled to Bali.

\section{Attractiveness of Bali Destinations According European Tourist}

Determine the variables that are considered eligible to be included in subsequent factor analysis, by imposing a number of tests on all variables, and remove variables that proved unfeasible. In this case the method KMO and Bartlett Test of Sphericity, measurement MSA (Measure of Sampling Adequacy) as well as testing with Anti Image Matrices. The test results as seen as on the Table 5 shows that the value of Kaiser-Meyer-Olkin Measure of Sampling Adequacy is about 0.840 which means the number of respondents statistically is adequate for factor analysis.

TABLE V. KMO AND BARTLETT'S TEST

\begin{tabular}{|c|c|r|}
\hline \multicolumn{2}{|c|}{ Kaiser-Meyer-Olkin Measure of Sampling Adequacy. } & 0.840 \\
\hline Bartlett's Test of & Approx. Chi-Square & 1153,343 \\
\cline { 2 - 3 } Sphericity & $d f$ & 105 \\
\cline { 2 - 3 } & Sig. & 0.000 \\
\hline
\end{tabular}

Extraction Method: Principal Component Analysis.

The factoring process is to do the extraction of the set of variables which are to determine one or more factors. The method used to perform the extraction process is the Principal Component Analysis. Table 6 shows that the results of the analysis that determined by the three components or factors with eigenvalues initial cumulative percentage about 59.838 percent.

TABLE VI. TOTAL VARIANCE EXPLAINED

\begin{tabular}{|c|r|r|r|}
\hline \multirow{2}{*}{ Component } & \multicolumn{3}{|c|}{ Initial Eigenvalues } \\
\cline { 2 - 4 } & Total & \% of Variance & Cumulative \% \\
\hline 1 & 5.765 & 38.433 & 38,433 \\
\hline 2 & 1.989 & 13.258 & 51,691 \\
\hline 3 & 1.222 & 8.147 & 59,838 \\
\hline
\end{tabular}

Extraction Method: Principal Component Analysis.

The next process is the process of rotation to determine factors. The results of the rotated analysis of Component Matrix as seen as Table 7 shows that the variable the beauty of the scenery, Balinese Culture, and History of Bali are formed as factor 3. While the variable prices of goods and services, events and festivals, variation tourist attractions, transportations, distance from the country of origin, varieties of culinary, hotel facilities and services are formed as factor 2, and variable of facilities and wellness services, immigration services, destination safety, quality of service travel agent, tour guide service are formed into factor 1 .

\begin{tabular}{|c|c|c|c|}
\hline \multirow[b]{2}{*}{ Variables } & \multicolumn{3}{|c|}{ Component } \\
\hline & 1 & 2 & 3 \\
\hline The beauty of the scenery & 0.065 & 0.314 & 0.813 \\
\hline Balinese Culture & 0.141 & 0.115 & 0.890 \\
\hline History of Bali & 0.053 & 0.062 & 0.758 \\
\hline Variations Travel Attractions & 0.270 & 0.635 & -0.034 \\
\hline Events and Festivals & 0.164 & 0.506 & 0.497 \\
\hline The Variant of Culinary & 0.091 & 0.689 & 0.111 \\
\hline Prices of Goods and Services & 0.308 & 0.648 & 0.227 \\
\hline Distance from Origin Country & 0.329 & 0.563 & 0.212 \\
\hline Facilities and Services Hotel & -0.007 & 0.616 & 0.206 \\
\hline Transportation & 0.361 & 0.612 & 0.130 \\
\hline Quality of Service Travel Agent & 0.549 & 0.296 & 0.381 \\
\hline $\begin{array}{l}\text { Facilities and Services } \\
\text { Wellness }\end{array}$ & 0.815 & 0.155 & 0.195 \\
\hline Security on Destinations & 0.788 & 0.148 & 0.084 \\
\hline Quality Services Guides & 0.849 & 0.145 & -0.034 \\
\hline Immigration services & 0.721 & 0.386 & 0.047 \\
\hline
\end{tabular}

Extraction Method: Principal Component Analysis. Rotation Method: Varimax with Kaiser Normalization. Rotation converged in 5 iterations.

Naming each of the factors that have been determined, it can be started from a factor that has the greatest eigenvalues to the smallest as sees as Table 8 below: 
TABLE VIII. NAMING FACTORS

\begin{tabular}{|c|c|c|c|c|}
\hline \multirow[t]{2}{*}{ Factor } & \multirow[t]{2}{*}{ Variables } & \multirow[t]{2}{*}{ Correlations } & \multicolumn{2}{|c|}{ Initial Eigenvalues } \\
\hline & & & Total & $\begin{array}{c}\% \text { of } \\
\text { Variance }\end{array}$ \\
\hline \multirow{5}{*}{$\begin{array}{l}\text { The immigration, } \\
\text { security of } \\
\text { destination, and } \\
\text { travel agencies }\end{array}$} & $\begin{array}{l}\text { Facilities and } \\
\text { Services Wellness }\end{array}$ & 0.549 & \multirow{5}{*}{5.765} & \multirow{5}{*}{38.433} \\
\hline & $\begin{array}{l}\text { Immigration } \\
\text { services }\end{array}$ & 0.815 & & \\
\hline & $\begin{array}{l}\text { Security on } \\
\text { Destinations } \\
\end{array}$ & 0.788 & & \\
\hline & $\begin{array}{l}\text { Quality of Service } \\
\text { Travel Agent }\end{array}$ & 0.849 & & \\
\hline & $\begin{array}{l}\text { Quality Services } \\
\text { Guides }\end{array}$ & 0.721 & & \\
\hline \multirow{7}{*}{$\begin{array}{l}\text { The prices, the } \\
\text { accommodation, } \\
\text { food and } \\
\text { transportation }\end{array}$} & $\begin{array}{l}\text { Prices of Goods } \\
\text { and Services }\end{array}$ & 0.635 & \multirow{7}{*}{1.989} & \multirow{7}{*}{13.258} \\
\hline & $\begin{array}{l}\text { Events and } \\
\text { Festivals } \\
\end{array}$ & 0.506 & & \\
\hline & $\begin{array}{l}\text { Variations Travel } \\
\text { Attractions }\end{array}$ & 0.689 & & \\
\hline & Transportation & 0.648 & & \\
\hline & $\begin{array}{l}\text { Distance from } \\
\text { Origin Country }\end{array}$ & 0.563 & & \\
\hline & $\begin{array}{l}\text { The Variant of } \\
\text { Culinary }\end{array}$ & 0.616 & & \\
\hline & $\begin{array}{l}\text { Facilities and } \\
\text { Services Hotel } \\
\end{array}$ & 0.612 & & \\
\hline \multirow{3}{*}{$\begin{array}{l}\text { The history, } \\
\text { culture, and } \\
\text { natural beauty }\end{array}$} & History of Bali & 0.813 & \multirow{3}{*}{1.222} & \multirow{3}{*}{8.147} \\
\hline & Balinese Culture & 0.890 & & \\
\hline & $\begin{array}{l}\text { The beauty of the } \\
\text { scenery }\end{array}$ & 0.758 & & \\
\hline
\end{tabular}

Test the accuracy of the model determine that "Residuals are computed correlations between observed and Reproduced are $53(50.0 \%)$ as non redundant residuals with absolute values greater than 0:05". The accuracy test means that the model has been formed trustworthy by $50 \%$.

\section{The main factors determine European tourist travel to Bali}

Factor analysis ultimately determines that there are three factors as the main attractions for European tourists to visit Bali which can be explained as follows: 1) the first factor is the factor of immigrations, security of destinations, and travel agencies services, with an initial strength of eigenvalues percentage of variance about $38.433 \%$. The first factor consists of facilities and wellness services, immigration services, security destinations, travel agent services quality, and service guides. 2) The second factor is the prices, accommodations, foods and beverages, and transportations, with the initial strength eigenvalues percentage of variance about $13.258 \%$. The second factor is composed of the prices of goods and services, events and festivals, variations tourist attraction, transportations, distance from the country of origin, culinary varieties, and the facilities and hotel services. 3) The third factor is the factor of history, culture, and natural beauty with an initial strength of eigenvalues percentage of variance about $8.147 \%$. The third factor is composed of History of Bali, Balinese Culture and the beauty of the scenery.

\section{E. Predominantly factors determine European tourist travel to Bali}

The dominant factors that determine the Europe tourists traveled to Bali can be explained as follows: The first factor is the most decisive European tourists coming to Bali are factors of immigration, security destinations, and travel agencies. The second factor that also determines European tourists traveled to Bali is the prices, accommodations, food and beverage, and transportation. While the last factor that determines the selection of European tourists traveling to Bali is factors of history, culture, and the beauty of the scenery.

\section{CONCLUSION AND RECOMMENDATIONS}

The three factors as the attraction of tourism Bali from perspective of Europe tourists are (1) the immigrations, security of destinations, and travel agencies, (2) the prices, the accommodations, foods and transports, (3) the history, culture, and natural beauty.

Whatever development strategy in order to increase the number of tourist arrivals from Europe country can be done by improving the quality of immigration services, destinations, improved the security, and improved quality of service travel agencies that focused by Europe tourists. The next strategy is to maintain the stability of prices of goods and services, especially those related to the supply of tourism sectors, maintaining the quality of accommodations, increasing the variety of culinary and arrangement of transportation services, especially related to transportation of tourists.

While the factors of history, culture, and the beauty of the scenery are a factor that needs to be maintained because these factors are the strength point of Bali destinations which is corroborated by the finding of the descriptive analysis of an average of the three variables are in the highest rank by perception of Europe tourists.

The study's findings also indicate that the image of Bali tourism destinations as the destination's history, culture, and nature. These three variables are in accordance with expectations of Europe tourists who have been known as tourists who interest the historical destinations, cultural tourisms, and the beauty of the sceneries. The implications of the research findings to destination promotional strategies is to highlight the power of destination with regard to the special interested in history, culture, and nature.

\section{ACKNOWLEDGMENT}

The author expresses the highest gratitude to The Directorate of Higher Education of Indonesia, the Rector of Bali Dhyana Pura University and the Chairman of Dhyana Pura Foundation who have given complete authorization for the author to undertake this research. Special thanks to Dhyana Pura student who participated in a volunteer team for the primary data collection of this study. 


\section{REFERENCES}

[1] Fakeye PC, Crompton JL. Image differences between prospective, firsttime, and repeat visitors to te Lower Rio Grande Valley. Journal of travel research. 1991 Oct;30(2):10-6.

[2] Jacoby J, Mazursky D. Exploring the development of store images. Journal of retailing. 1986;62(2):145-65.

[3] Tasci AD, Gartner WC, Tamer Cavusgil S. Conceptualization and operationalization of destination image. Journal of hospitality \& tourism research. 2007 May;31(2):194-223.

[4] Keown C, Jacobs L, Worthley R. American tourists' perception of retail stores in 12 selected countries. Journal of Travel Research. 1984 Dec;22(3):26-30.

[5] Milman A, Pizam A. The role of awareness and familiarity with a destination: The central Florida case. Journal of travel research. 1995 Jan;33(3):21-7.

[6] Goeldner, Charles R, Ritchie., J.R. Brent., McIntosh, Robert W. . Tourism - Principles, Practices, Philisophies. 8th ed., John Wiley \& Sons, Inc, p.637-644. 1999.
[7] Chi, Gengqing, "A Study of Developing Destination Loyalty Model". (Dissertation) Submitted to the Faculty of the Graduate College of the Oklahoma State University in Partial Fulfillment of the Requirements for the Degree of Doctor of Philosophy, July 2005

[8] Coban S. The effects of the image of destination on tourist satisfaction and loyalty: The case of Cappadocia. European Journal of Social Sciences. 2012;29(2):222-32.

[9] Jamaludin, Mazlina., Shazali Johari., Azlizam Aziz., Kalsum Kayat., Abdul Raheem Mohamad Yusof.. Examining Structural Relationship between Destination Image, Tourist Satisfaction and Destination Loyalty. International Journal of Independent Research and Studies IJIRS. ISSN: 2226-4817; EISSN: 2304- 6953, Vol. 1, No.3 (July, 2012)

[10] Santoso, Singgih.. Pengolahan Statistik dengan SPSS, Andi. Jogjakarta. 2015 